\title{
THE EFFECT OF LACTIC ACID BACTERIA AND DIFFERENT LEVEL OF CARBOHYDRATE SOURCES ADDITION ON TOFU WASTE INDUSTRY FERMENTATION ${ }^{1}$
}

\section{PENGARUH BAKTERI ASAM LAKTAT DAN PENAMBAHAN SUMBER KARBOHIDRAT PADA KADAR BERBEDA TERHADAP FERMENTASI LIMBAH INDUSTRI TAHU}

\author{
Zaenal Bachruddin*, Era Rahmawat Agustiani and Lies Mira Yusiati \\ Faculty of Animal Science, Gadjah Mada University, Yogyakarta, 55281
}

Submitted: 3 April 2017, Accepted: 20 July 2017

\begin{abstract}
The purpose of this research was to figure out the affinity value of soluble carbohydrates from pollard with lactic acid bacteria $(\angle A B)$ and its effect on tofu waste silage. Lactic acid bacteria ( $L A B)$ isolates used as inoculum were commerce $L A B$ isolates (B13-1) and yolk LAB isolates (K6-3). The selected of $L A B$ isolates used in the tofu waste silage were tofu waste (TW) and pollard (P) with different proportion (70:30), $(60: 40)$, and (55:45). The result showed that the addition of soluble carbohydrates sources in the tofu waste silage did not affect lactic acid and $\mathrm{pH}$ value. However, $\mathrm{LAB}$ addition significantly increased lactic acid $(P<0.05)$. The TW:P proportion (55:45) produced the highest lactic acid concentration with the value of 3.54\%DM with $\mathrm{pH}$ value 3.90. Proportion of TW:P gave significant effect on dry matter (DM) and organic matter $(\mathrm{OM})(\mathrm{P}<0.01)$. Meanwhile, LAB addition presented significant difference in declining of dry matter percentage $(P<0.01)$ but it showed non-significant effect on organic matter percentage from the tofu curd silage. It can be concluded that pollard addition with the value of $45 \%$ shows that tofu waste silage has the highest lactic acid concentration and ideal $\mathrm{pH}$ value.
\end{abstract}

(Keywords: Lactic acid bacteria (LAB), Silage, Tofu waste)

\section{INTISARI}

Tujuan dari penelitian ini adalah untuk mengetahui nilai afinitas kadar karbohidrat pada polard sebagai sumber karbohidrat terhadap kinetika fermentasi bakteri asam laktat (BAL) dan pengaruhnya terhadap fermentasi limbah industri tahu. Isolat BAL yang digunakan adalah (B13-1) dan (K6-3 yang merupakan hasil isolasi dari sumber BAL komersial dan sumber BAL pada medium yang mengandung kuning telur. Macam perlakuan fermentasi BAL terhadap limbah industri tahu, secara berturut turut mempunyai rasio antara limbah tahu (LT) dan pollard (P) adalah sebagai berikut: (70:30); (60:40) dan (55:45). Hasil penelitian menunjukan bahwa penambahan sumber karbohidrat terhadap fermentasi LT tidak memberikan pengaruh terhadap nilai asam laktat dan $\mathrm{pH}$. Akan tetapi penambahan BAL meningkatkan kadar asam laktat secara signifikan $(P<0,05)$. Rasio antara $L T$ dan $P(55: 45)$ menghasilkan nilai kadar asam laktat tertinggi dengan nilai $\mathrm{pH}$ sebesar 3,90. significantly different effect on dry matter (DM) and organic matter $(O M)(P<0,01)$. Berbagai level Rasio antara LT:P memberikan pengaruh terhadap kadar bahan kering (BK) dan bahan organik (BO). Disamping itu penambahan BAL menunjukan penurunan kadar bahan kering secara signifikan $(P<0,01)$,akan tetapi tidak menunjukan perbedaan terhadap bahan organik pada fermentasi LT. Melalui penelitian dapat disimpulkan bahwa penambahan polard dengan nilai sebesar $45 \%$ telah memberikan kadar asam laktat tertinggi dengan nilai $\mathrm{pH}$ yang ideal.

(Kata kunci: Bakteri asam laktat (BAL), Fermentasi, Limbah tahu)

${ }^{1}$ Selected paper of the $1^{\text {st }}$ International Conference on Tropical Agriculture (ICTA) 2016

${ }^{*}$ Korespondensi (corresponding author):

Telp. +62811255922

E-mail: bachrudin@ugm.ac.id 


\section{Introduction}

Semi-intensive and intensive ruminant production in Indonesia is characterized by a high demand and dependencyy of concentrate (mixed cereals) which are expensive. This makes feeds to be high, which represents $60-70 \%$ of the economic input in the livestock production system. The optimal utilization of local natural resources is a strategic step in achieving business efficiency ruminant livestock production in Indonesia. The raw materials generally associated with industrial-waste processing industry are the primary raw materials of agricultural origin. Nkosi et al. (2010), feed cost and animal competition with humans for feed item, strongly suggest that alternative energy sources such as food by-product is used partially or totally to replace cereals in livestock diet to reduce and enhance cheaper meat production.

Not only could the by-products be utilized as a source of nutrients for ruminants, but they can also be used to replace imported commercial feedstuffs to save energy in transportation, and, possibly, to reduce the environmental impact of burning them as waste of burying them in landfills. Xu et al. (2001) reported that food by-product such as tofu waste is high in crude protein and fatty acid. Katayama (2001) and Osaka (2001) implied that many food by-products are high in moisture content and often stored by ensiling them to avoid the energy costs of drying. Although some wet by-products can be ensiled without any additives, much cost is wasted on transporting water rather than nutrients. Imai (2001) stated that preparing total mixed ration (TMR) silage is one practice where by food by-products are stored and utilized as animal feeds in Japan. Our previous study (Cao et al., 2009) shows that TMR silage with $30 \%$ dried tofu waste has the higher lactic acid content than that with rice bran or green tea waste. Segawa (1991) reported that in tofu curd mixed with rice straw produces good silage and is ready to use by livestock in Japan.

However, even if there is plenty of glucose as a substrate, if it is insufficient in lactic acid bacteria, preparing good quality silage is difficult. Many researchers report that molasses addition can stimulate fermentation by supplying substrates for the growth of lactic acid bacteria (Guo et al., 2014). Cai et al. (1999) reported that the factors involved in fermentation quality include chemical composition, particularly the water-soluble carbohydrates content of the silage material, and physiological properties of epiphytic bacteria.

During ensiling, lactic acid bacteria (LAB) is used as additives to increase the preservation of nutritive value of feedstuff and enzyme activity, and to inhibited deleterious epiphytic microbial populations. $L A B$ isolates (B13-1) and yolk LAB isolates (K6-3), inoculated in this study, are facultative homofermentative $L A B$, and able to ferment a wide variety of substrates and quickly produce large amounts of lactic acid. The purpose of this experiment was to examine the effects of $\mathrm{LAB}$ inoculant on the tofu curd silage, and to figure out the affinity value of soluble carbohydrates from pollard with $L A B$ and its effect on tofu curd silage.

\section{Materials and Methods}

\section{Ensiling}

Composition of tofu waste silage before being fermented shows at Tabel 1. Curd waste silage was mixed with tofu waste (TW) and pollard $(P)$ as the main ingredient with different proportion. The tofu waste silage was TW and $P$ with different proportion (70:30), (60:40), and (55:45). Targeted DM tofu waste silage was respectively 30 to $45 \%$ of DM. The experiment was ensiled with or without $L A B$ inoculant. The inoculant used in this study were, $L A B$ isolates (B13-1), and $L A B$ isolates $(\mathrm{K} 6-3)$, and those isolate were homofermentative LAB. The persentage of the inoculants appliedd $10 \%$ of fresh tofu waste silage. The tofu waste silage was stored in vacuum-packed plastic pouches. Fresh by-products or tofu curd silage mixtures $(300 \mathrm{~g})$ were put into a pouch, and an airtight silo was prepared by using a vacuum sealer. Respectively, Silage was made in triplicate and stored at ambient temperature at $25^{\circ} \mathrm{C}$ for 21 days.

\section{Chemical analysis}

Moisture, ash, crude protein, ether extract, and crude fibre contents were determined by general methods. The $\mathrm{pH}$ of the silage was determined using a glass electrode of $\mathrm{pH}$ meter (D-21, Horiba, Kyoto, Japan). Lactic acid was analysed using the method of Barker and Summerson (Hawk et al., 1954). 
Buletin Peternakan Vol. 41 (3): 279-284, Agustus 2017 Bulletin of Animal Science, DOI: 10.21059/buletinpeternak.v41i3.23677

Table 1. Composition of tofu curd silage before being fermented

\begin{tabular}{lccccc}
\hline \hline \multicolumn{1}{c}{ Nutrient composition } & Tofu curd (TC) & Pollard (P) & \multicolumn{3}{c}{ TC: P } \\
\cline { 3 - 6 } & & & $70: 30$ & $60: 40$ & $55: 45$ \\
\hline Moisture (\%) & 89,56 & 12,05 & 66,63 & 60,54 & 55,91 \\
Dry matter (DM) (\%) & 10,44 & 87,95 & 33,37 & 38,46 & 44,09 \\
Organic matter (\% of DM) & 96,46 & 94,22 & 94,09 & 94,07 & 94,02 \\
Crude protein (\% of DM) & 20,21 & 13,79 & 21,93 & 16,96 & 15,96 \\
Crude fibre (\% of DM) & 20,50 & 12,95 & 15,20 & 14,07 & 12,82 \\
Ether extract (\% of DM) & 1,72 & 4,40 & 3,96 & 4,94 & 5,07 \\
Nitrogen free extract (\% of DM) & 54,03 & 63,08 & 53,00 & 58,10 & 60,17 \\
\hline
\end{tabular}

Author: Nutritional Biochemistry Laboratory Faculty of Animal Science Gadjah Mada University.

\section{Statistical analysis}

Data of $\mathrm{pH}$ value, lactic acid production of tofu curd silage, and dry matter (DM) and organic matter (OM) of tofu curd silage opened after day 21 was analysed using a completely randomized design with $3 \times 3$ (variety of proportion $\times$ additive treatment) factorial treatment structure.

\section{Result and Discussion}

\section{$\mathrm{pH}$ value}

Fermentation process on tofu curd silage causes $\mathrm{pH}$ value to be low. $\mathrm{pH}$ value measurement resulted in tofu curd silage is presented in Table 2.

Based on the result presented in Table 2 , the different proportion of dissolved carbohydrate source showed a very significant effect $(P>0.01)$ on $\mathrm{pH}$ value changes, and the addition of LAB-showed also significant effect $(P<0.05)$ whereas the interaction between those two treatments didn't show a significant effect. All treatments reached the critical $\mathrm{pH}$ value with a mean 3.80 to 3.90 simultaneously on day 21 . It shows that all treatments produced successful tofu curd silage because of the formation of the LAB. Meeske et al. (2002) showed that the fermentation of corn (maize silage) with addition of lactic acid bacterial inoculants gives a decrease of $\mathrm{pH}$ value more than what is expected - which is about 3.90 to 3.85 . Gao et al. (2008) reported that, after 30 days of fermentation, the acidic smell formed by straw fermentation using lactic acid bacteria with $\mathrm{pH}$ 3.8 is lower than the control (4.1). Danner et al. (2003) implied that corn silage with addition of homo-fermentative bacteria has about 3.8 of $\mathrm{pH}$ value and lactic concentration between 31.9 to $35.4 \mathrm{~g} / \mathrm{kg}$, while the corn silage with addition of hetero-fermentative bacteria has the highest $\mathrm{pH}$ value which is 4.11 .

\section{Lactid acid production}

Based on the result presented in Table 3 , it can be concluded that the proportion of dissolved carbohydrate in tofu curd silage did not give effect on the level of lactic acid $(P<0.05)$, but the three treatments gave different result of lactic acid production. The proportion of tofu curd and pollard (55:45) produced lactic acid with the highest average which is $3.54 \% \mathrm{BK}$. However, other results present that the addition of LAB significantly affected the levels of lactic acid $(P<0.05)$. High content of BETN was more susceptible to degradee resulting in a higher lactic acid production. The result showed that the proportion BETN tofu curd and pollard $(55: 45)$ by $60.17 \%$ higher lactate production compared to $(70: 30)$ by $53 \%$ and $(60: 40)$ by $58.10 \%$. Hartadi et al. (1999) reported that the extract without nitrogen-containing mono-, di, tri- and tetra-saccharides and starch added by some material substances includes hemicellulose. Molin (2008) reported that L. plantarum is a homo-fermentative bacteria which is able to utilize $100 \%$ of carbohydrates in the form of glucose or other simple sugar. The more complex sugar bonding that occurs in carbohydrate, the lower capability of L. Plantarum to utilize these carbohydrate.

The addition of soluble carbohydrate can improve the quality of fermented silage using LAB. Hhigher concentration of soluble carbohydrate will increase the production of lactic acid, and lower the propionic acid and butyric acid. At an excessive concentration of dissolved carbohydrates, production of lactic acid will be saturated. High concentration of lactic acid can reduce the loss of crude protein which occurs during the ensilage process (Yang et al., 2006). Lactic acid levels in total mixed ration silage (TMR) which uses tofu curd for 14 days of incubation by $1.9 \%$, while BK for 56 days of incubation produce lactic acid levels by $2.53 \%$ BK. Total mixed 
Table 2. $\mathrm{pH}$ value on tofu curd silage

\begin{tabular}{lcccc}
\hline \hline \multirow{2}{*}{ Additive treatment } & \multicolumn{3}{c}{ Curd tofu : pollard } & \multirow{2}{*}{ Mean treatment } \\
\cline { 2 - 4 } & $70: 30$ & $60: 40$ & $55: 45$ & \\
\hline Control & $3.78 \pm 0.010$ & $3.84 \pm 0,006$ & $3.89 \pm 0,006$ & $3.84 \pm 0.004^{\mathrm{a}}$ \\
LAB B13-1 & $3.80 \pm 0.006$ & $3.85 \pm 0,006$ & $3.91 \pm 0,010$ & $3.86 \pm 0.004^{\mathrm{b}}$ \\
LAB K6-3 & $3.80 \pm 0.015$ & $3.84 \pm 0,020$ & $3.91 \pm 0,006$ & $3.85 \pm 0.004^{\mathrm{b}}$ \\
\hline Mean proportion & $3.80 \pm 0.004^{\mathrm{x}}$ & $3.85 \pm 0,004^{\mathrm{y}}$ & $3.90 \pm 0,004^{\mathrm{z}}$ & \\
a,b Means in the same column with different superscripts $(\mathrm{P}<0.05)$. & \\
x,y,z Means in the same row with different superscripts (P<0.01).
\end{tabular}

Table 3. Lactic acid (\%DM) on tofu curd silage

\begin{tabular}{lcccc}
\hline \hline \multirow{2}{*}{ Additive treatment } & \multicolumn{3}{c}{ Curd tofu : Pollard } & \multirow{2}{*}{ Mean treatment } \\
\cline { 2 - 4 } & $70: 30$ & $60: 40$ & $55: 45$ & \\
\hline Control & $2.68 \pm 0.262$ & $3.31 \pm 0.418$ & $2.93 \pm 0.260$ & $2.97 \pm 0.214^{\mathrm{a}}$ \\
LAB B13-1 & $3.41 \pm 0.281$ & $3.98 \pm 0.644$ & $3.60 \pm 0.966$ & $3.75 \pm 0.215^{\mathrm{b}}$ \\
LAB K6-3 & $3.01 \pm 0.573$ & $2.56 \pm 1.140$ & $3.80 \pm 0.571$ & $3.13 \pm 0.214^{\mathrm{a}, \mathrm{b}}$ \\
\hline Mean proportion $^{\mathrm{s}}$ & $3.03 \pm 0.214$ & $3.29 \pm 0.214$ & $3.54 \pm 0.214$ & \\
\hline
\end{tabular}

${ }_{\mathrm{a}, \mathrm{b}}$ Means in the same column with different superscripts $(\mathrm{P}<0.05)$.

Table 4. Percentage of dry matter (\%DM) on tofu curd silage

\begin{tabular}{lcccc}
\hline \hline \multirow{2}{*}{ Additive treatment } & \multicolumn{3}{c}{ Curd tofu : pollard } & \multirow{2}{*}{ Mean treatment } \\
\cline { 2 - 4 } & $70: 30$ & $60: 40$ & $55: 45$ & $37.21 \pm 0.186^{\mathrm{c}}$ \\
Control & $31.74 \pm 0.270$ & $38.48 \pm 0.221$ & $41.40 \pm 0.285$ & $35.46 \pm 0.186^{\mathrm{b}}$ \\
LAB B13-1 & $30.20 \pm 0.106$ & $36.11 \pm 0.046$ & $40.08 \pm 0.181$ & $34.77 \pm 0.186^{\mathrm{a}}$ \\
LAB K6-3 & $29.95 \pm 0.289$ & $34.78 \pm 1.544$ & $39.58 \pm 0.268$ & \\
\hline Mean proportion & $30.63 \pm 0.186^{\mathrm{x}}$ & $36.46 \pm 0.186^{\mathrm{y}}$ & $40.35 \pm 0.186^{\mathrm{z}}$ & \\
\hline a,b,c Means in the same column with different superscripts $(\mathrm{P}<0.01)$. & \\
x,y,z Means in the same row with different superscripts $(\mathrm{P}<0.01)$. &
\end{tabular}

Table 5. Percentage organic matter (OM) of \%DM on tofu curd silage

\begin{tabular}{lcccc}
\hline \hline \multirow{2}{*}{ Additive treatment } & \multicolumn{3}{c}{ Curd tofu : pollard } & \multirow{2}{*}{ Mean treatment ${ }^{\mathrm{ns}}$} \\
\cline { 2 - 4 } & $70: 30$ & $60: 40$ & $55: 45$ & \\
\hline Control & $94.46 \pm 0.197$ & $94.37 \pm 0.041$ & $94.42 \pm 0.092$ & $94.42 \pm 0.068$ \\
BAL B13-1 & $94.65 \pm 0.021$ & $94.38 \pm 0.070$ & $94.25 \pm 0.072$ & $94.44 \pm 0.068$ \\
BAL K6-3 & $94.73 \pm 0.433$ & $94.11 \pm 0.355$ & $94.11 \pm 0.058$ & $94.31 \pm 0.068$ \\
\hline Mean proportion & $94.61 \pm 0.068^{y}$ & $94.29 \pm 0.068^{\mathrm{x}}$ & $94.26 \pm 0.068^{\mathrm{x}}$ & \\
\hline
\end{tabular}

${ }^{x, y}$ Means in the same row with different superscripts $(P<0.01)$.

ration (TMR) silage which uses beer dregs produces lactic acid levels by $1.15 \%$ during the 14 day incubation, while BK for 56 day incubation produces lactic acid level by $1.56 \%$ BK (Wang and Nishino, 2008).

\section{Dry matter (DM) and organic matter (OM) on tofu curd silage}

The result of observation of dry matter and organic matter in tofu curd silage at $21 \mathrm{~d}$ was presented in Table 4 and 5.

The result presented in Table 4 shows that the difference of soluble carbohydrate source proportion and addition of LAB significantly affects DM of tofu curd silage $(P<0.01)$ with significant interaction $(P<0.05)$. Addition of bacteria reduces percentage of DM of tofu curd silage significantly. The lowest reduction of percentage of DM occurs on k 6-3 treatment $(34.77 \%)$, B13-1 (35.46\%), and control $(37.21 \%)$. The highest percentage of DM reduction occurred on K-63 treatment proves bacteria ability in optimal utilization of soluble carbohydrate. Based on the result presented in table 5 , it shows that proportion of soluble carbohydrate gives significant effect on OM of tofu curd silage $(P<0.01)$. However, addition of $\angle A B$ does not affect the percentage of OM of tofu curd silage $(P<0.05)$.

Some hydrolysis process which break hemicellulose into pentose occurs during fermentation process (McDonald et al., 2002). Liu et al. (2009) reported that quality of fermentation product which has moderate KA $(60.24 \%)$ is better than fermentation product which has high KA $(73.68 \%)$ and low KA $(28.88 \%)$. 


\section{Conclusion}

It can be concluded that pollard addition with the value of $45 \%$ shows that tofu curd silage has the highest lactic acid concentration with ideal $\mathrm{pH}$ value, and has the highest dry matter. Whereas, addition of LAB increases lactic acid significantly. The tofu curd silage having some beneficial could be included as component of ration in livestock industry.

\section{Acknowledgments}

This research was granted by Ministry of Research, Technology and Higher Education of the Republic of Indonesia and Nutritional Biochemistry laboratory, Animal Nutrition and Feed Department. Faculty of Animal Sciences, Gadjah Mada University.

\section{Reference}

Cai, Y., Y. Benno, M. Ogawa, S. Kumai. 1999. Effect of applying lactic acid bacteria isolated from forage crops on fermentation characteristics and aerobic deterioration of silage. $\mathrm{J}$. Dairy Sci. 82: 520-526.

Cao, Y., T. Takahashi, and K. Horiguchi. 2009. Effect of food by-products and lactic acid bacteria on fermentation quality and in vitro dry matter digestibility, ruminal methane and volatile fatty acid production in total mixed ration silage with whole-crop rice silage. Japanese J. Grass. Sci. 55: 1-8.

Danner, H., M. Holzer, E. Mayrhuber, and R. Braun. 2003. Acetic acid increases stability of silage under aerobic conditions. J. Appl. Environ. Micro. 69: 562-567.

Gao, L., Y. Hongyan, W. Xiaofen, H. Zhiyong, I. Masaharu, I. Yasuo, and C. Zongjun. 2008. Rice straw fermentation using lactic acid bacteria. J. Bio Technol. 99: 2742-2748.

Guo, G., X. Yuan, L. Li, A. Wen, and T. Shao. 2014. Effects of fibrolytic enzymes, molasses and lactic acid bacteria on fermentation quality of mixed silage of corn and hulless-barely straw in the Tibetan Plateau. Grassl. Sci. 60: 240-246.

Hartadi, H., S. Reksohadiprojo, dan A. D. Tillman. 1999. Komposisi Pakan Ternak untuk Indonesia. Gadjah Mada University Press, Yogyakarta.
Hawk, P. B., B. L. Oser, and W. H. Summerson. 1954. Practical Physiologic Chemistry. McGraw-Hill Book Company, INC, New York.

Imai, A. 2001. Silage making and utilization of high moisture by-products. 1. Significance of silage making for highmoisture by-products. Grassl. Sci. 47: 307-310.

Katayama, N. 2001. Silage making and utilization of high-moisture by-products. 2. Nutritive characteristics and preservation method of by-products. Grassl. Sci. 47: 311-317.

Liu, Q., J. Zhang, and X. Lu. 2009. The effects of lactic acid bacteria inoculation on the fermentation quality and aerobic stability of king grass silage. Acta Prataculturae Sinica, 18: 131-137. (in Chinese).

McDonald, P., R. A. Edwards, J. F. D. Greenhalgh, and C. A. Morgan. 2002. Animal Nutrition. $6^{\text {th }}$ edn. Ashford Colour Press Ltd, Gosport.

Meeske, R., G. D. van der Merwe, J. F. Greyling, and C. W. Cruywagen. 2002. The effect of the addition of a lactic acid bacterial inoculant to maize at ensiling on silage composition, silage intake, milk production and milk composition. J. Anim. Sci. 32: 263-270.

Molin, G. 2008. Lactobacillus plantarum: The role in food and in human health. In: Handbook of Fermented Functional Food. E. R. Farnworth (Ed). $2^{\text {nd }}$ edn. CRC Press Taylor and Francis Group, Boca Raton.

Nkosi, B. D., R. Meeske, H. J. van der Merwe, O. Acheampong-Boateng and $\mathrm{T}$. Langa. 2010. Effects of dietary replacemen of maize grain with popcorn waste products on nutrient digestibility and performance by lambs. South Afr. J. Anim. Sci. 40: 133-139.

Osaka, N. 2001. Silage making and utilization of high-moisture by-products. 5 . Silage making and utilization of apple pomace. Grassl. Sci. 47: 327-331.

Segawa, T. 1991. Mixed silage processing system using drum-silo. Information of the Results of Research on Grassland and Forage. 6: 55-56.

Wang, F. and N. Nishino. 2008. Ensiling of soybean curd residue and wet brewers grains with or without other feeds as a total mixed ration. J. Dairy Sci. 91: 2380-2387. 
Xu, C. C., H. Suzuki, and K. Toyokawa. 2001. Characteristics of ruminal fermentation of sheep fed tofu cake silage with ethanol. J. Anim. Sci. 7: 299-305.

Yang, H. Y., X. F. Wang, J. B. Liu, L. J. Gao, M. Ishii, Y. Igarashi, Z. J. Cui. 2006. Effects of water-soluble carbohydrate content on silage fermentation of wheat straw. J. Bio. Bioengineering 101: 232237 